\title{
The level of insurance knowledge of young people entering professional life - results of questionnaire surveys conducted among students of the Podkarpackie Voivodship
}

\author{
JarostaW Wenancjusz PRZYBYTNIOWSKI ${ }^{1}$ \\ Jan Kochanowski University in Kielce, Institute of Management
}

\begin{abstract}
The purpose of the article is to analyse the importance of insurance knowledge as one of the main determinants of changes in the insurance awareness of young people entering professional life in the decision-making process of selecting insurance coverage in the business insurance sector. Bearing in mind the above research purpose, it has been assumed that The insurance knowledge of individual customers entering professional life forces the increase in the awareness related to activities connected with ensuring the safety of the customers of insurance companies when choosing the insurance coverage option. Data were collected with the use of questionnaire surveys.

Both subject literature and empirical research have confirmed the hypothesis that highlights the role of insurance knowledge in raising the awareness of young people entering professional life.
\end{abstract}

Paper type: research article

Keywords: insurance knowledge, awareness, consciousness, customer, voluntary insurance, sphere of real economy

1 j.w.przybytniowski@wp.pl 


\section{Introduction}

In the state financial system, the economic insurance market is one of the basic components of this market. It is distinguished by the complicated arrangement of economic, guarantee and investor relations, as well as mechanisms of legal regulations, which relate to different areas of law. The functions of insurance companies, which act as a kind of "lubricant" for the economy, are an important matter in insurance business. Any disruption to this arrangement creates problems in the sphere of not only state finances but also individual entities interested in the stability of the financial market, undermining trust in the whole financial syste (Przybytniowski, 2009, 2016). One should keep in mind that insurance appears both within financial services and as a scientific discipline.

The subject literature does not clearly present one standard model that would explain the impact of insurance knowledge on the growth of the awareness of the customers of insurance companies. It also does not answer the question Is the insurance knowledge factor, which should affect the awareness of customers of insurance companies in one separate enterprise, a more advantageous solution than designing one standard model? (Altkorn \& Kramer, 1998; Bennion, 1969; Christopher, Payne, \& Ballantyne, 1991; Cummins \& Doherty, 2006; Łańcucki, 2003, 2008; Mayerson, 1962). As a consequence, having adequate insurance knowledge to increase the customer's insurance awareness becomes an important factor in the insurance management process. This factor affects the quality of service management. The service quality is the final product of the complex management and operation process of the insurance company (cf. Przybytniowski, 2013).

The main purpose of the study is to analyse insurance knowledge as one of the main determinants of changes in the insurance awareness of young people entering professional life, in the decision-making process of choosing insurance coverage in the business insurance sector. Bearing in mind the above research purpose, it has been assumed that The insurance knowledge of individual customers entering professional life forces the increase in the awareness related to activities connected with ensuring the safety of the customers of insurance companies when choosing the insurance coverage option. The data was collected with the use of a questionnaire conducted among students. Statistical methods were used for data analysis.

\section{Insurance knowledge - theoretical approach}

\section{Insurance knowledge and education}

The analysis of the available literature of the subject indicates that the concept of knowledge has not been uniquely defined in general terms (Pacholarz, 2016; Przybytniowski \& Pacholarz, 2015; Przybytniowski, 2014) and in relation to insurance 
services (see: Łazowski, 1928; Łańcucki, 2003). It should be emphasized that knowledge is an inherent and immaterial element of human reality. Without it - there is no way to function properly. And perhaps that is why it is justified for the world of science to make further attempts to face this issue and to clarify this problem - even if it were merely about drawing attention to certain aspects of that concept. ${ }^{2}$

According to Lazowski (1928), insurance knowledge is a set of scientificallyinformed messages aimed at understanding the essence and principles of insurance business and determining the conditions for its further development. Olejnik i Białowąs (2015) argue that insurance knowledge is an element of financial knowledge and includes all the information that is necessary to understand all issues related to the proper functioning of the insurance market. According to the same $\mathrm{Au}$ thors, knowledge can be analyzed at the subjective (assessment of own knowledge) and objective level. In the paper it is assumed that insurance knowledge is "a set of scientifically arranged pieces of information which are supposed to help know the essence and basic principles of insurance as well as the conditions of their further development in a changing environment" (Przybytniowski, 2007, pp. 111-118; 2009, pp. 199-208).

According to the research by Pieńkowska-Kamieniecka and Walczak (2016), insurance knowledge has a strong influence on the growth of awareness in this area, and consequently - having adequate insurance coverage corresponding to the customer needs. One can conclude that economic insurance knowledge is a synthesis of the academic achievements of many sciences, including economics, law, mathematics, statistics, chemistry, sociology, psychology, natural sciences and medicine. It is needed in many occupations (Leśniewski, 2015).

To be able to correctly define the concept of insurance knowledge, one should pay attention to education, i.e. schooling and training, which lead to deepening the awareness of people who often make life decisions. Education is about learning and teaching someone. It is multi-faceted and can be analyzed in many contexts, on different levels. The aim of insurance education is not only to provide knowledge and to indicate the ways to use it, but above all, to stimulate and develop the awareness of people involved in the educational process, and through them, across the whole society.

\section{Insurance awareness}

Szumlicz (2006, pp. 21-26) defines awareness as knowledge and skills that allow rational use of insurance coverage and, consequently, demonstrate appropriate insurance precaution and, as a consequence, a sense of awareness.

Insurance consciousness is the concept of "consciousness or awareness" in the context of the satisfaction of the insurance company customer needs when decid-

2 The origins of this term are attributed to the ancient Athenian philosopher Socrates, who argued that knowledge is conviction supported by reasoning; Stefanowicz, 2011. 
ing to conclude an insurance contract. According to Płonka (2010), individual insurance awareness is a general set of views and beliefs common to whole groups, classes and societies relating to the scope and form of threats to their existence, as well as overall means of eliminating or reducing such impacts. It is the result of the influence of the socio-cultural environment and, at the same time, its developmental factor. This awareness is defined in six areas (Szromnik, 2001):

- needs and in particular the extent and scale of safety needs,

- knowledge of security measures,

- own insurance experience,

- environment-specific customs and traditions,

- insurance marketing of companies and

- insurance education of society (Figure 1).

These categories are of an individual nature. Areas shaping the actual level of insurance awareness can be appropriately stimulated by means of marketing and educational instruments (Przybytniowski, 2009). Consequently, insurance awareness can be defined as a set of knowledge components on the functioning of the mechanisms regulating the insurance market, which is the basis for making the right choices affecting the sense of security, and consequently the quality of life of an individual.

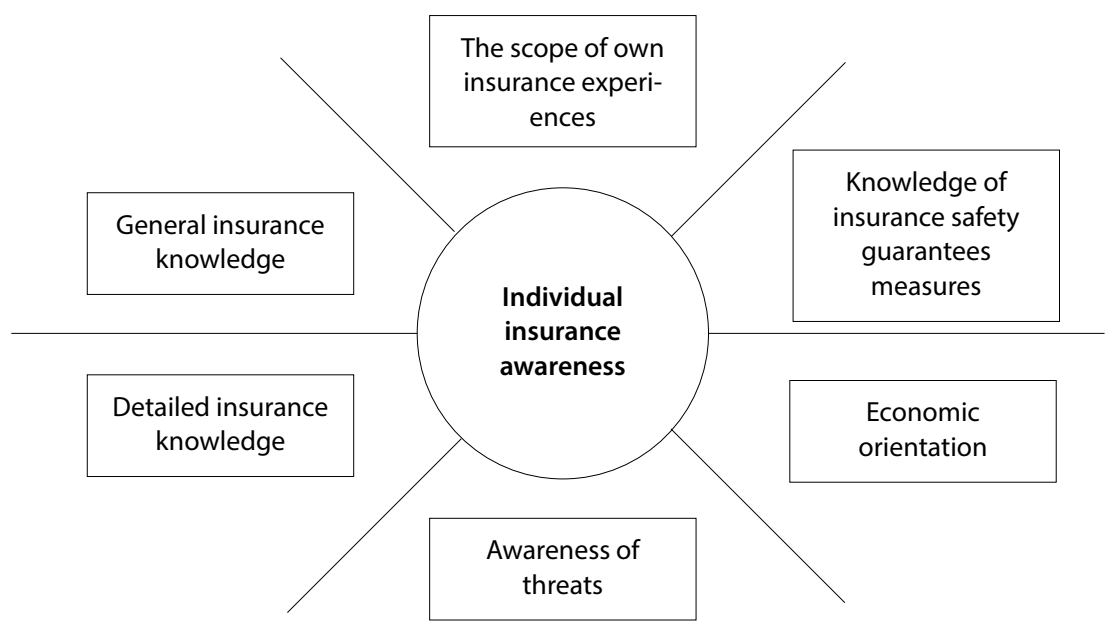

Figure 1. Operational components of individual insurance awareness.

Source: based on Szromnik, 2001, pp. 33-35. 
Insurance awareness raises the need for qualified security measures, including formal non-insurance measures. There are two types of dependencies between the demand for insurance or non-insurance safety guarantee measures (Sułkowska, 2001):

- Substitute dependencies (insurance service replaces other qualifying, incidental means of eliminating dangers, e.g. security systems, alarm systems, property protection).

- Complementary dependencies (the insurance contract complements other measures that are sometimes necessary for its conclusion).

The measurement of individual insurance awareness can be direct - conducted in the cross section of specific individuals or secondary - expressing the quantitative characteristics of the attitudes, behaviours and decisions of whole groups as well as the resources of their general knowledge and specific (specialist) insurance knowledge. There is an important link between insurance awareness and insurance knowledge. Without knowing the rules of the insurance market and the extent of insurance coverage and, therefore, risk awareness, it is difficult to expect customers to take action to expand their knowledge about that matter. However, when the need for an insurance contract is recognized, an adequate level of insurance knowledge is an essential prerequisite to skilfully take advantage of the wide range of insurance products available on the market to meet the needs expected. Thus, insurance awareness is connected with and is determined by the level of insurance knowledge, i.e. knowledge about certain aspects of the preparation and planned acquisition of adequate insurance coverage by the customer. Knowledge about specific risks that affect the amount of premium paid and knowledge about the characteristics and functioning of the insurance market - as a whole (cf. Prast \& van Soest, 2015). The relationship between insurance awareness, insurance knowledge and the expected level of security and satisfaction with one's insurance coverage is shown in the Figure 2.

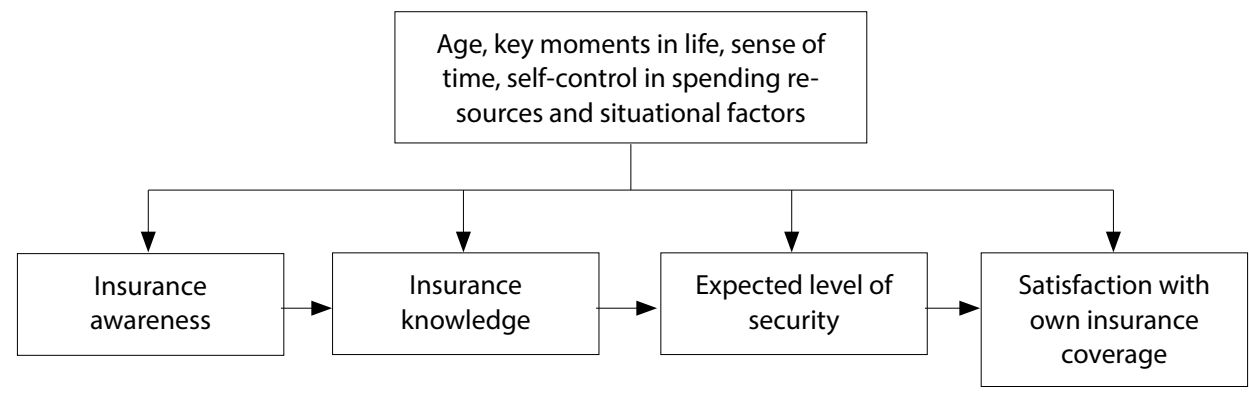

Figure 2. The relationship between insurance awareness, insurance knowledge, the expected level of security and satisfaction with own insurance coverage. 
It should be noted that insurance awareness is not considered a final goal in the insurance management strategy. Managers of insurance companies generally do not perceive information and communication in the insurance market as merely a tool to increase the knowledge of their customers but as a means of making them aware of certain actions they must take. It is essential to ensure that customers, thanks to the knowledge they have, are aware and take the necessary steps to ensure themselves adequate compensation or benefits. Thanks to this, they know how, what option to choose and when to decide to enter into an insurance contract - depending on their needs and the preferred standard of living.

\section{Awareness of security needs versus insurance awareness}

The awareness of threats is influenced by the general perception of reality, the way one experiences and feels it. Categories related to general and specific insurance knowledge and non-insurance safety guarantee measures are directly connected with the general knowledge of an individual, their level of education, the individual need for such knowledge and the desire to acquire it. General and specific insurance knowledge is a highly individualized category. Knowledge of non-insurance security guarantee measures - is the knowledge of security systems: locking, alarms, monitoring systems, fire protection, security systems, etc., which allow to choose the way of protecting material goods. It is the area of marketing and information impacts of insurance companies.

Awareness of security needs is shaped by the sphere of threats and means of security guarantee measures and does not correspond to insurance awareness. As a consequence, a conscious need for safety generates momentary insurance awareness, which is strongly linked to the level of individual risk-taking and awareness of the effects of one's needs not being satisfied (see: Szromik, 2001; Przybytniowski, 2016). According to Pacholarz (2016) - needs, knowledge and individual experiences regarding insurance can be stimulated through a variety of instruments, such as, self-education, opinions from the environment in which a person operates and in contact with insurance agents and employees. The process of shaping insurance awareness focuses on coordinated experiences, information, incentives, both in an individual and their immediate surroundings, in insurance companies and other external companies responsible for coordinating and maintaining public policy, but not directly related to the insurance market. The goal of increasing public insurance awareness is to increase the demand for conscious insurance coverage (Lazowski, 1928 ) and increased distribution of insurance contracts. With this in mind, one can say that the increase in insurance awareness stimulates the development of the insurance market, and thus the real economy. 


\section{Research methodology}

\section{Results of current studies - literature review}

According to Atkinson and Kempson (2004), young people are prone to spending money and spending it in the least thoughtful and an excessive way. Nearly half of 18-24 year olds taking part in the Survey of Over-Indebtedness in the United Kingdom claimed that they make spontaneous purchasing decisions without thinking about whether or not they can afford a certain product.

Marketing has an ambiguous influence on spending and saving. Young people indicate that the culture of saving and good practices in financial risk behaviours should be the subject of educational activities and should be promoted by various public and financial institutions while marketing messages have a demotivating effect on saving. Dolphin (2012) examined this issue on the example of banks. He concluded that many banks encouraged young people to set up savings accounts mainly due to the possibility of incurring overdraft fees to finance their purchases. As a result, the desire to save money became of lesser importance for owners of such accounts.

Based on the assumptions of the behavioural theory of saving (Beverly et al., 2008), it can be pointed out that even if people want to save, they must face the strong desire to spend their money for other purposes. This, of course, affects people of all ages, but it is especially young people who have different priorities, prefer "careless youth" and do not think about retirement, and thus do not ensure themselves additional resources for the post-retirement period. Unlike the neoclassical theory of economics, the assumptions of the behavioural theory of saving do not presume that people - facing various dilemmas and financial problems - behave in a rational way. The basic assumptions of behavioural economics in terms of saving and capital accumulation are presented in Table 1.

The subject literature related to behavioural ${ }^{3}$ economics theory identifies certain characteristics of norms and behaviours that influence the way people manage their financial resources and their approach to saving. Among them there is: hyperbolic discounting, social norms, status quo bias, or presentation of possible choices. Behavioural anthropologists also assume that a person is characterized by limited cognitive abilities, tends to interpret and treat certain default options as alternatives to what is advised to them by others, and to use mental calculation ${ }^{4}$ techniques in

3 Behavioural economics is a field of study that combines the accomplishments of economics and psychology. Its roots go back to the behavioural psychology trend which focuses on the behaviour and environmental stimuli controlling it. The creation and development of this trend took place in the 30s. Watson and Skinner (read more in: Bąbel \& Ostaszewski, 2008) are considered its precursors.

4 Term "mental calculation" refers to situations in which people think differently about spending their money, depending on their source. 
Table 1 Basic characteristics of behavioural economics theory

\begin{tabular}{|c|c|c|}
\hline Basic individual assumptions & Basic areas & Explanation \\
\hline $\begin{array}{l}\text { - They have limited knowledge } \\
\text { regarding finances } \\
\text { - They are impatient, they } \\
\text { attach too much attention to } \\
\text { current affairs without think- } \\
\text { ing about the future } \\
\text { - They choose the simplest } \\
\text { non-complex way of func- } \\
\text { tioning (e.g. preferring the } \\
\text { status quo } \\
\text { - They are overwhelmed by } \\
\text { information and a number } \\
\text { of choices } \\
\text { - They tend to use mental } \\
\text { calculation techniques } \\
\text { - they bear mental costs }\end{array}$ & $\begin{aligned} \text { - } & \text { Financial knowledge } \\
\text { - } & \text { Self-control } \\
\text { - } & \text { Established obligations } \\
\text { - } & \text { Analysis of mental costs } \\
\text { - } & \text { Inertia } \\
\text { - } & \text { Perfecting choices in the } \\
& \text { simplest way known ("thumb } \\
& \text { rule") }\end{aligned}$ & $\begin{array}{l}\text { - Individuals make decisions } \\
\text { later on due to the lack of } \\
\text { knowledge and competence } \\
\text { - Even when individuals want } \\
\text { to save, they have the temp- } \\
\text { tation to spend money } \\
\text { - People are naive in their in- } \\
\text { decisiveness and do not take } \\
\text { into account their obligations } \\
\text { and financial constraints in } \\
\text { the future }\end{array}$ \\
\hline
\end{tabular}

Source: Beverly et al., 2008, pp. 89-151.

relation to savings (Beverly et al., 2008). Status quo bias means and refers to a situation in which people are conservative in making every decision, even when there is no concrete evidence that they use it more than the alternative status. A number of factors influence whether a person remains within this status. De Meza, Irlenbusch and Reyniers (2008) distinguish postponing (putting off until "tomorrow") (Sieczkowski, 2015), aversion to losses and information overload. Young people are also prone to hyperbolic discounting which makes it much harder for them to save. Preferring something at the moment instead of having money in the future means that they would rather have a smaller amount now than a bigger one in the future (Dolphin, 2012). Consequently, these tendencies lead to behaviours that are incompatible with own priorities and needs. This does not lead to maximization of consumption over a long period of time.

When analysing how these characteristics affect young people and their approach to financial issues, one should also make use of the knowledge about the economic and financial conditions in which their parents were raised, their attitude to saving and financial knowledge (Berry, 2011). As it turns out, parents have a lot of influence over whether young people save money or not. According to the research by Dolphin (2012) about 75\% of young people claimed that their approach to saving is the same as their parents', while only $6 \%$ said that they were not influenced by their parents. Parents are the first source of information on financial issues and have a great impact on financial decisions made by young people. According to NOP Research Group, almost 90\% of 15-19 year olds ask their parents for advice regarding their money management (Labrum, Spires, Jones, \& Godfrey, 2004). In addition, Kempson and Finney (2009) show that encouraging saving from an ear- 
ly age translates into money-saving behaviours in later life. Every third person who disagreed with the statement that they had been encouraged by parents to save did not do so in adult life. Pathak, Holmes, and Zimmerman (2011) draw attention to the difficulty connected with young people introducing different saving behaviours at their own households than those they learned from the family home, which is also affected by the material situation of their family home. Wealthier parents were generally more knowledgeable and had more financial skills to share with their children. On the other hand, less affluent parents - even though they had lower financial competences, were more likely to talk about finances with their children due to their constant attention to the state of the home budget. As a consequence, young people from wealthier families turned out to be less attached to money and thinking about saving (Labrum et al., 2004).

\section{Method and test}

The data were collected with the use of surveys conducted in years 2015/2016 based on the author questionnaire. It included a general section containing questions related to the metrics of the respondents and a detailed section on the assessment of insurance knowledge and insurance awareness. Assessment of the level of insurance knowledge and awareness of students was conducted through a five-point Likert scale, based on which the author could receive a response related to the degree of acceptance of the analysed phenomenon. The proposed scale consisted of the cafeteria grouping together five responses according to the degree of total acceptance -5 to total rejection -1 . The responder was asked to determine to what extent they agree with the question, where: 1 - meant very low, 2 - meant low, 3 - meant average, 4 - meant high, 5 - very high.

The survey was carried out in the direct form among students of extramural studies, working and residing in the Podkarpackie Voivodship. Sample selection (Table 2) consisted of 500 respondents. Out of 500 questionnaires that contained questions on subjective and objective insurance knowledge (20 questions), 450 were complete, which ensured the representativeness of the surveyed population, $55.2 \%$ of women and $44.8 \%$ of men. The majority of students were of $26-27$ and $24-25$ years of age, respectively (25.6\% and $22.2 \%)$, and they constituted $47.8 \%$ of all the respondents. People over 30 years of age were the smallest group surveyed (8.8\%), $20-21$ years (12.5\%) and $28-29$ years $(13.8 \%)$. 
Table 2 Structure of the test sample

\begin{tabular}{|l|l|c|c|}
\hline Variable & \multicolumn{1}{|c|}{ Variable value } & Number & Percent \\
\hline \multirow{3}{*}{ Sex } & female & 247 & 55.2 \\
\cline { 2 - 4 } & male & 203 & 44.8 \\
\hline \multirow{4}{*}{ Age } & $20-21$ years old & 57 & 12.5 \\
\cline { 2 - 4 } & $22-23$ years old & 77 & 17.1 \\
\cline { 2 - 4 } & $24-25$ years old & 100 & 22.2 \\
\cline { 2 - 4 } & $26-27$ years old & 115 & 25.6 \\
\cline { 2 - 4 } & 28-29 years old & 62 & 13.8 \\
\cline { 2 - 4 } & over 30 years of age & 39 & 8.8 \\
\hline \multirow{3}{*}{$\begin{array}{l}\text { Place of } \\
\text { residence }\end{array}$} & rural areas & 89 & 19.8 \\
\cline { 2 - 4 } & below 10 thousand residents & 93 & 20.7 \\
\cline { 2 - 4 } & from 10 to 50 thousand residents & 97 & 19.3 \\
\cline { 2 - 4 } & from 50 to 100 thousand residents & 83 & 21.8 \\
\cline { 2 - 4 } & from 100 to 500 thousand residents & & 18.4 \\
\hline
\end{tabular}

Note: $N=450$.

\section{Research results}

The survey conducted (Table 3 ) shows that appropriate remuneration (66.1\%), better financial education (63.4\%) and favourable tax incentives (59.2\%) could significantly influence the decision to sign an insurance contract.

Table 3 Factors leading to increased interest in signing an insurance contract among academic youth between 2015 and 2016 for people aged 20-30 (in \%)

\begin{tabular}{|l|c|c|c|}
\hline \multicolumn{1}{|c|}{ Factor } & 2015 & 2016 & $\begin{array}{c}\text { Change } \\
\text { 2016/2015 (\%) }\end{array}$ \\
\hline Appropriate remuneration & 57.2 & 66.1 & 115.6 \\
\hline Better financial education & 56.3 & 63.4 & 112.6 \\
\hline Favourable tax incentives & 54.7 & 59.2 & 108.2 \\
\hline Access to professional financial advisors & 38.3 & 44.5 & 116.9 \\
\hline Good retirement plan & 23.4 & 29.6 & 126.5 \\
\hline Simple investment products & 18.9 & 22.2 & 117.5 \\
\hline Help with legal protection & 15.3 & 19.2 & 125.5 \\
\hline Others & 6.2 & 8.2 & 132.3 \\
\hline No interest in the subject & 3.8 & 7.7 & 202.6 \\
\hline I don't know & 1.8 & 3.8 & 211.1 \\
\hline
\end{tabular}


Another question related to the needs of young people entering adult, professional life. According to the results obtained, young people pay close attention to the pay-related benefits that will allow them to meet their current needs. More than $90 \%$ of respondents were interested in this factor (we can see a significant growth of this factor between 2015 and 2016). To a lesser extent, respondents drew attention to what will happen once they approach retirement age, as well as the knowledge of insurance products, especially products that are not obligatory. These factors were of interest to less than $50 \%$ of the respondents. And here too, one could notice the significant dynamics of growth. The subjective assessment of the economic knowledge on insurance confirms these results. Respondents answered the question: How do you assess your general insurance knowledge? (Figure 3).

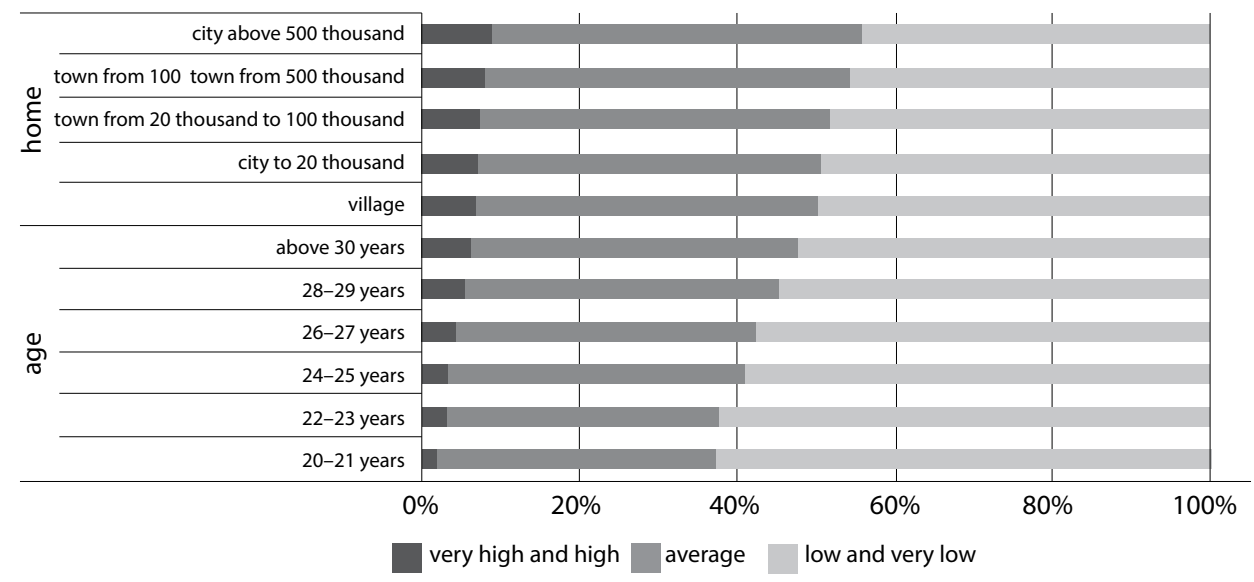

Figure 3. How do you assess your general insurance knowledge?

Note: $N(2016)=450$.

Responders believe that their insurance knowledge is very low and low (such responses were provided by $52.6 \%$ responders in 2015 and 51.6\% in 2016). Subsequently, respondents assessed their level of insurance knowledge as average, and in $2015-41.7 \%$, and in $2016-43.8 \%$. The data show that during the survey period the percentage of students assessing their insurance knowledge as low and very low decreased in comparison to those who assessed their knowledge as average. By contrast, compared to 2015 , there was a $2 \%$ decrease in the number of people assessing their insurance knowledge as: Really high and high, in comparison to those who rated it as average.

With respect to selected demographic profiles (place of residence and age), respondents aged 20-21 years living in rural areas declare lower levels of knowledge. Respondents who declare that their insurance knowledge is average - are people 
over 30 years of age and 28-29 years of age, who live in the city from 100 to 500 thousand residents. With respect to year 2015, in both cases, there was a $2.5 \%$ decrease in the number of respondents who assessed their insurance knowledge as low and very low in comparison to the responders who assessed it as average.

Based on the research results, it is difficult to conclude that the age of students is a factor differentiating the level of insurance knowledge and awareness. Students of all ages begin the process of education and work which is also a source of information and building insurance awareness.

A further stage of the study was the analysis of the insurance knowledge of students, based on the insurance knowledge indicators developed on the basis of the knowledge test (answers to the questions regarding insurance). The questions concerned, among others: knowledge of insurance products, ability to manage own financial portfolio, organization of insurance market, social insurance, saving and investing principles.

The analysis of insurance knowledge test showed that the knowledge of students is much higher than their subjective assessment. A little more than $42 \%$ of responders gave correct answers (high, very high), and more than $24 \%$ of the respondents gave average answers. Fewer than 6 correct answers were indicated by more than $17 \%$ of respondents. The obtained result shows a low level of insurance knowledge of the students surveyed. Compared to the survey conducted in 2015, the percentage of respondents whose knowledge can be classified as low, average and high, decreased slightly but it did not make a significant statistical difference.

One of the simplest questions for the students surveyed was the question about managing their own financial resources. Only $52 \%$ of respondents indicated an incorrect answer, which is $15.9 \%$ of total respondents. Another relatively simple question related the organization of the insurance market - nearly $32 \%$ of students responded correctly. A similar result to the previous question related to the knowledge of insurance mediation, more than $25 \%$ of all respondents. On the other hand, the most problematic questions related to: pension benefits $-65.6 \%$, life insurance contracts (division I) - 56.7\%, property insurance contracts (division II) $47.1 \%$ and the legal functioning of the insurance market $-41.1 \%$ of the total number of students surveyed. The reason is that current and potential customers, who have a low level of insurance knowledge, do not believe in real insurance coverage and conclude only obligatory insurance contracts ignoring other insurance products (Przybytniowski, 2016, pp. 176-185). Compared to 2015, the percentage of students who responded correctly to almost all questions increased (for three questions, the changes were significant). The biggest increase (by almost 27\%) was recorded for the question related to the organization of the insurance market.

Given the demographic profiles (residence and age), it is difficult to clearly indicate the extent to which age has an effect on the level of the responses. Respondents in the age range of 24-27 (12.3\%) provided the biggest number of correct answers. Students aged 20-21 (21.6\%) have, according to the data obtained, the lowest level of in- 
surance knowledge. Results of the 24-27-year-old responders living in a large city confirm the results obtained by the author from the subjective assessment of respondents.

When referring to the research assumptions, in the context of a functioning market economy, entities offering insurance services in the form of different insurance contracts, when seeking customers, create new strategies and ways of managing insurance companies. This should be done through a systematic assessment and analysis of the insurance market, and consequently modifications of insurance products, also targeted at the young generation, taking into account their needs and the globalization of the market. The current premium-based strategy of insurance companies, which is often the only criterion for acquiring customers, led in many disappointments (see: Rzecznik finansowy, 2017, pp. 77-97). This encouraged managers of insurance companies to focus in their strategies on insurance knowledge and awareness of customers of insurance companies, where the quality of service is of vital importance.

\section{Conclusions}

The analysis of the level of insurance knowledge in the respondents of higher education institutions in the Podkarpackie Voivodeship reveals that over half of the students surveyed have big deficiencies in this area. On the other hand, noticeable changes can be seen in the subjective assessment of insurance knowledge, where a significant percentage of knowledge assessment as high and very high have been reduced when compared to average assessments. The level of knowledge is lower in 2016 than in 2015 (practically in all areas a statistically significant change is noted).

At the same time, there was no difference in the variables examined, such as, sex, age, place of residence of the student in the surveyed voivodeship and insurance knowledge and awareness. Current expenditure and excessive lifestyle, make young people less likely to have a sense of security, which is reflected in the decision to save for retirement, but only in the future, or knowledge of insurance products. In addition, an adequate level of awareness is essential to make optimum financial decisions, especially those relating to the insurance needs of young people. Therefore, what seems necessary is proper financial education at various levels of adolescence and exposure of behavioural factors that have a significant impact on young people's saving decisions. It also involves building the appropriate climate of competence, trusting financial institutions and other entities involved in the performance of functions and the tasks of the insurance market.

Looking forward, in addition to organizational and infrastructural solutions, should be the key to success for any developing economy that wants to have its say on the global arena. It is appropriate at this point to take into account the Florida's (2010) thesis of three "Ts" - talent, technology and tolerance, so that creativity and innovation have the chance to prosper. 


\section{References}

Altkorn, J., \& Kramer, T. (eds.) (1998). Leksykon marketingu. Warszawa: Polskie Wydawnictwo Ekonomiczne.

Atkinson, A., \& Kempson, E. (2004). Young People, Money Management, Borrowing and Saving. A Report to the Banking Code Standards Board. Personal Finance Research Centre (UK), retrieved from: http://www.pfrc.bris.ac.uk/Reports/BCSB_young_people.pdf [accessed: 30.12.2017].

Bąbel, P., \& Ostaszewski, P. (eds.) (2008). Współczesna psychologia behawioralna. Wybrane zagadnienia. Kraków: Wydawnictwo Uniwersytetu Jagiellońskiego.

Bennion, F. (1969). Professional ethics. In J. Pietrzak (2000). Sektor usług profesjonalnych modelowy wzorzec zarządzania. Marketing i Rynek, (4), 8-9.

Berry, C. (2011). Resuscitating Retirement Saving. How to Help Today's Young People Plan for Later Life. London: The International Longevity Centre-UK (ILC-UK).

Beverly, S., Sherraden, M., Zhan, M., Williams Shanks, T.R., Nam, Y., \& Cramer, R. (2008). Determinants of Assets Building. A Report in the Series Poor Finances: Assets and Low-Income Households, pp. 89-151.

Christopher, M., Payne, A., \& Ballantyne, D. (1991). Relationship Marketing: Bringing Quality, Customer Service and Marketing. Oxford (UK): Butterworth Heinemann, pp. 5-27.

Cummins, J.D., \& Doherty, N.A. (2006). The Economics of insurance intermediaries. Journal of Risk and Insurance, 73(3), 359-396.

De Meza, D., Irlenbusch, B., \& Reyniers, D. (2008). Financial Capability: A Behavioural Economics Perspective. London: Financial Services Authority.

Dolphin, T. (2012). Young People and Savings: A Route to Improved Financial Resilience. London: IPPR.

Florida, R. (2010). Narodziny klasy kreatywnej. Warszawa: Narodowe Centrum Kultury.

Kempson, E., \& Finney, A. (2009). Saving in Lower-income Households: A Review of the Evidence. Bristol: Personal Finance Research Centre.

Labrum, C., Spires, P., Jones, C., \& Godfrey, L. (2004). Young People (18-24) and Their Financial Information Needs. Consumer Research 44. London: Financial Services Authority.

Łańcucki, J. (ed.) (2003). Podstawy kompleksowego zarządzania jakościa TQM. Poznań: Akademia Ekonomiczna w Poznaniu.

Łańcucki, J. (2008). Jakościowe aspekty rozwoju rynku ubezpieczeniowego. Prawo Asekuracyjne, (1), 4-13.

Łazowski, J. (1928). Wiedza ubezpieczeniowa w Polsce. Ekonomista, (2), 34-36.

Leśniewski, M.A. (2015). Wiedza w strategiach zarządzania przedsiębiorstwem. Zarządzanie wiedzą. Studium teoretyczne. In J. Jaskiernia, R. Kubicki (eds.), Ekonomia, zarzadzanie i rozwój regionalny. Pomiędzy światem polityki a życiem naukowym, vol 3. Kielce: Uniwersytet Jana Kochanowskiego w Kielcach, pp. 171-187.

Mayerson, A.L. (1962). Introduction to Insurance. New York: Macmillan.

Olejnik, I., \& Białowąs, S. (2015). Pension literacy and consumers' decisions in the context of pension system reforms. Problemy Polityki Społecznej, (2), 13-33.

Pacholarz, W.M. (2016). Pojęcia wiedzy w teorii ekonomii. Ekonomika i Organizacja Przedsiębiorstwa, (8), 3-19.

Pathak, P., Holmes, J., \& Zimmerman, J. (2011). Accelerating Financial Capability among Youth: Nudging New Thinking. Global Assets Project. Washington: New America Foundation.

Pieńkowska-Kamieniecka, S., \& Walczak, D. (2016). Willingness of Polish households to save for retirement. European Financial Systems 2016. Proceedings of the $13^{\text {th }}$ International Scientific Conferences, Brno, June 27-28, 588-595. 
Płonka, M. (2010). Determinanty konkurencyjności zakładów ubezpieczeń w Polsce. Prace Naukowe Uniwersytetu Ekonomicznego we Wrocławiu, (105 Ubezpieczenia Gospodarcze), 192-198.

Prast, H., \& van Soest, A. (2015). Pension Awareness, Pension Communication, and Choice Architecture. Netspar \& Tilburg University.

Przybytniowski, J.W. (2007). Edukacja ubezpieczeniowa i jej wpływ na świadomość ubezpieczeniową (wybrane problemy). Rozprawy Ubezpieczeniowe, (1(2)), 111-118.

Przybytniowski, J.W. (2009). Rola edukacji ubezpieczeniowej w procesie rozwoju rynku ubezpieczeniowego. Studia i Prace Uniwersytetu Ekonomicznego w Krakowie, (7), 199-208.

Przybytniowski, J.W. (2013). Konkurencyjność rynku usług pośrednictwa ubezpieczeniowego $w$ Polsce. Warszawa: Wydawnictwo Menedżerskie PTM.

Przybytniowski, J.W. (2014). Wiedza jako jeden z czynników wzrostu jakości usług ubezpieczeniowych. In R. Borowiecki, A. Jaki (eds.), Restrukturyzacja w obliczu wyzwań gospodarki globalnej. Kraków: Fundacja Uniwersytetu Ekonomicznego w Krakowie, pp. 195-204.

Przybytniowski, J.W. (2016). Współczesne funkcje i mechanizmy transmisji między sektorem ubezpieczeniowym a sfera realna gospodarki. Teoria i praktyka. Warszawa: CeDeWu.

Przybytniowski, J.W., \& Pacholarz, W.M. (2015). Knowledge management as a growth factor for the competitiveness of the insurance sector. Research your own. International Journal of Recent Scientific Research, 6(10), 1-9.

Rzecznik finansowy. (2017). Ubezpieczenia szkolne. Warszawa, retrieved from: http://rf.gov. $\mathrm{pl} / \mathrm{pdf} /$ Raport-ubezp\%20szkolne-wersja\%20ost-czerwiec\%202017.pdf [accessed: 20.06 . 2017].

Sieczkowski, W. (2015). Decyzje oszczędnościowe w systemie zabezpieczenia emerytalnego. In M. Kawiński (ed.), Ubezpieczenie społeczne. Idea i kontynuacja. Warszawa: SGH, pp. 87-105.

Stefanowicz, B. (2011). Wiedza. Wybrane zagadnienia. Warszawa: Oficyna Wydawnicza SGH.

Sułkowska, W. (ed.) (2001). Bariery rozwoju polskiego rynku ubezpieczeniowego. Kraków: Zakamycze.

Szromnik, A. (2001). Rynek ubezpieczeniowy. Społeczne problemy ksztattowania i funkcjonowania. Kraków: Akademia Ekonomiczna w Krakowie.

Szumlicz, T. (2006). Atrybuty świadomości i przezorności ubezpieczeniowej. Rozprawy Ubezpieczeniowe, (1), 21-26.

\section{Note about the Author}

JarosŁaw Wenancjusz Przybytniowski - Ph.D. in economics (2000), Institute of Management, Faculty of Management and Administration of the Jan Kochanowski University in Kielce. Employment: Assistant Professor at the Jan Kochanowski University in Kielce (2002). Scientific achievements: 3 author monographs, 2 co-author monographs; 101 scientific articles published in national and foreign scientific journals. Participant of 10 academic internships with invitation lectures in England and Germany. Active participation in national (61), international (29) and foreign (16) seminars and conferences. Research: 9 national and international research projects. Awards received: 1998-1999 (3) and in 2012 Prof. Tadeusz Sangowski' name (1). Organizer of postgraduate studies: "Project management." Cooperation with national, international and foreign scientific and research institutions. Research interests: financial market, including insurance market. 